\title{
Does Trade Openness Matter for Economic Growth in the CEE Countries?
}

\section{Bernard Njindan Iyke ${ }^{1}$}

\begin{abstract}
This paper sets out to answer the question: Is trade openness important for economic growth in the Central and Eastern European (CEE) countries? The policyoriented measures of trade openness used in earlier studies have been argued to be subjective, while the simple outcome-oriented measures only capture one aspect of trade openness, namely: countries' share of trade. Hence, following Squalli and Wilson (2011), the paper constructs a new outcome-oriented measure of trade openness which captures a country's share of trade, and its interaction and interconnectedness with the rest of the world. Using fixed-effects regressions for $17 \mathrm{CEE}$ countries over the period $1994-2014$, the paper finds trade openness to be important for growth within the CEE countries. In particular, the results show that increases in trade openness is associated with increases in real GDP per capita growth within these countries. The results appear significantly the same after we dropped Croatia and Estonia - two historically closed economies.
\end{abstract}

Key words: CEE Countries, Economic Growth, Panel Data, Trade Openness

JEL Classification: C23, F43

Received: 29 August 2016 / Accepted: 2 December 2016/Sent for Publication: 21 March 2017

\section{Introduction}

Does trade openness benefit or harm economic activities? This question has attracted an endless debate in the literature. Extensive studies on the impact of trade openness on various macroeconomic, institutional, and environmental variables exist today (see, among others, Edwards, 1993; Frankel and Romer, 1999; Treisman, 2000; Greenaway et al., 2002; Pernia and Quising, 2003; Li et al., 2004; Frankel and Rose, 2005; Neumayer and Soysa, 2005; Aizenman and Noy, 2006; Chintrakarn and Millimet, 2006; Cavallo and Frankel, 2008; Chang et al., 2009; Nannicini and Billmeier, 2011).

This paper joins these studies by attempting to answer the above question, by concentrating on the Central and Eastern European (CEE) countries. The CEE countries are made up of all countries which were historically in the Eastern bloc, west of the postWorld War II border with the former Soviet Union, the independent states in former

\footnotetext{
${ }^{1}$ Department of Finance, Deakin Business School, Deakin University, Melbourne Burwood Campus, Australia. Email address: benitoflex@gmail.com.
}

C 2017 by the authors; licensee Review of Economic Perspectives / Národohospodárský obzor, Masaryk University, Faculty of Economics and Administration, Brno, Czech Republic. This article is an open access article distributed under the terms and conditions of the Creative Commons Attribution 3.0 license, Attribution - Non Commercial - No Derivatives. 
Yugoslavia, and the three Baltic states of Estonia, Latvia, and Lithuania (see World Bank, 2008). These countries were formerly communist states, which have undertaken extensive political, economic and institutional reforms during the past three decades. Nearly all these countries have implemented trade liberalization policies in order to open up their markets to external participants. Hence, these countries provide a suitable sample to attack this overarching question. There are some existing studies which considered these countries in their samples as well. For example, Nannicini and Billmeier (2011), studying transition countries, including the CEE countries, find trade liberalization to exert a positive impact on growth. Awokuse (2007) finds trade to stimulate growth in the CEE countries in his sample. Wacziarg and Welch (2008) find trade liberalization to promote growth using a new dataset which includes selected CEE countries. Notably, the existing studies have produced conflicting findings, leaving the abovementioned question open for further investigation.

Additionally, the previous studies have either used policy-oriented measures of trade openness which are known to be subjective or they used outcome-oriented measures of trade openness that may only capture a country's share of trade. This paper attempts at using a newly developed measure of trade openness that is as objective as possible, while at the same time captures the dimensions of trade openness, including a country's share of trade, and its interaction and interconnectedness with the rest of the world. The paper builds on the novel lead by Squalli and Wilson (2011), who propose and construct this new measure of trade openness for a broad cross-section of countries. As opposed to their work, however, we construct the measure of trade openness for a panel of relatively homogenous group of countries, the CEE countries. Using fixed-effects regressions for 17 CEE countries over the period 1994 - 2014, we find trade openness to be an important predictor of growth within the CEE countries. In particular, the results show that an increase in trade openness is associated with an increase in real GDP per capita growth within these countries. Our results remain significantly unaffected after we dropped Croatia and Estonia - two historically 'closed' economies. This suggests that the two 'closed' economies may not be driving our results.

The rest of the paper is organized as follows. In the next section, we review the related literature on trade openness and growth. In section 3 , we discuss the measures of trade openness, the data and the empirical model. Section 4 presents the empirical results. Section 5 concludes the paper.

\section{Related Literature}

A large body of studies has been dedicated to providing answers to the important question of whether trade openness matters for growth. And in fact, the links between these two variables have been blurred by various factors (see Nannicini and Billmeier, 2011). Studies such as Dollar (1992), Sachs and Warner (1995), Edwards (1992, 1998), and Vamvakidis (2002) document evidence in favour of a positive effect of trade openness on growth; while Alcalá and Ciccone (2004) demonstrate that the effects work primarily through total factor productivity.

Theoretically, one cannot disagree that trade openness has several benefits, the most important being knowledge and technological spillovers (see Falvey et al., 2004). The resulting knowledge and technological spillovers may generate increasing returns and 
contribute to faster long-run growth (Squalli and Wilson, 2011). In addition, higher exports may promote real output expansion (Helpman and Krugman, 1985), whereas higher imports may exert downward pressures on the costs of production (Markusen et al., 1995). In contrast, trade openness may carry debilitating factors into an economy. More opened economies may be more vulnerable to imported inflation, boom-bust cycles of investment, volatile exchange rates, dumping, negative external shocks, among others (see Gavin and Hausmann, 1996; Rodrik, 1999; Acemoglu et al., 2003; Razin et al., 2003; Combes and Saadi-Sedik, 2006; Koren and Tenreyro, 2007; Malik and Temple, 2009; Montalbano, 2011).

To really understand the relationship between trade openness and growth, the empirical literature provides extensive discussion on what trade openness means. Generally, two sets of measures have emerged in the literature. These are policy stance and trade outcome measures (see Nannicini and Billmeier, 2011; Squalli and Wilson, 2011). The former considers the nature of trade policies, thereby leading to binary indicators denoting closed or opened economies; and the latter expresses the size of countries' international transactions, normally expressed in terms of GDP. The outcome-oriented measures of trade openness are argued to be prone to endogeneity issues. To overcome the endogeneity issues, various studies utilize instrumental variables (see, for example, Frankel and Romer, 1999). The trade policy stance measures are also said to be very subjective since the researchers are left to decide what factors would make a country "open" or "closed". Moreover, such measures often permit researchers to estimate cross-country regressions (see Sachs and Warner, 1995), which suffer from sample limitations (Rodriguez and Rodrik, 2001).

To improve on the sample limitation problem, Harrison (1996) proposes the use of panel regressions; she uses fixed-effects estimators to estimate the relationship between trade openness and growth. In addition, Wacziarg and Welch (2008) expand and update the Sachs-Warner (1995) dataset and modify the policy stance measure. By estimating cross-country regressions based on this new dataset, Wacziarg and Welch (2008) find the positive association between trade openness and growth as documented in Sachs and Warner (1995) to vanish. However, they find positive association between trade openness and growth to hold when they estimate panel regressions.

Other studies advance difference-in-differences techniques to answer the above question. Slaughter (2001) assesses the effect of four very specific trade liberalization events on income growth dispersion, and finds no systematic link between trade liberalization and per capita income convergence. Estevadeordal and Taylor (2008) consider the GATT Uruguay Round (UR) as a treatment and compare pre- and post-UR experience for a set of countries (between 31 and 75 countries, depending on the specification); they find that trade liberalization (their preferred measure is constructed from tariffs on imported capital and intermediate goods) appears to be consistent with faster GDP growth. Moreover, Giavazzi and Tabellini (2005) also apply a difference-in-differences approach to study the interactions between economic and political liberalizations. They find a positive and significant effect of economic liberalization on per capita income growth of: $0.9 \%$ if a country only opened to trade; $2.2 \%$ if a country opened to trade first and then experienced also political liberalization. Furthermore, they show that the sequencing matters in that it is advantageous, from a growth perspective, to first liberalize the trade regime and only later the political environment. 
In their study, Bhagwati and Srinivasan (2002) challenge the previous studies by arguing that the techniques used are not suitable for pinning down a concrete nexus between trade and growth. They argue, in particular, against the use of cross-country regressions, highlighting that researchers often choose sample periods and proxies that inherently generate the results they want to see. They argue for detailed case studies in order to establish a robust link between trade and growth. Pritchett (2000) reaches this conclusion earlier in his study. Later, Billmeier and Nannicini (2009) demonstrate a potential limitation of cross-country estimates of the effect of trade openness on growth, using an empirical strategy based on non-parametric matching estimators. Specifically, they show that if openness to trade is not evenly distributed over the covariate space (i.e. almost all countries with certain characteristics are either open or closed), then the evidence based on cross-country estimations would not be reliable. Nannicini and Billmeier (2011) revisit the trade-growth nexus by closely looking at a panel of transition economies. They control for treatment endogeneity using synthetic control methods and find trade openness to promote growth.

As argued by Rodriguez and Rodrik (2001), the role of trade openness in growth remains a very open debate, thereby paving way for further investigations. Our paper is loosely related to that of Harrison (1996) in that we attempt to answer the above question by using fixed-effects estimators, which improves upon the parameter estimates of cross-country regressions. The paper is also loosely related to Nannicini and Billmeier (2011) because we closely consider a panel of relatively homogenous countries - the Central and Eastern European (CEE) countries - thereby surmounting the cross-country heterogeneity problem associated with cross-country regressions. These countries are relatively homogenous in that they are located in the same hemisphere and have relatively similar or the same institutional setups, political history, economic background, and initial endowments. Most importantly, our paper is closely related to Squalli and Wilson (2011) who recommend outcome-oriented measures when testing the opennessgrowth hypothesis because they are easily obtainable from objective data sources. Unlike the outcome-oriented measures, the policy-oriented measures are often contrived, leading to varieties of policy-oriented measures being proposed in the literature (see, for example, Edwards, 1998). Following Squalli and Wilson (2011), we construct an index of trade openness that captures countries' share of trade, interaction and interconnectedness with the rest of the world. ${ }^{2}$ This index is more powerful than the existing outcomeoriented measures that only capture the relative position of a country's trade performance compared with its domestic economy. Such measures are limited because they tend to penalize larger economies by ranking them as closed when in fact they may not be (see Frankel, 2009; Squalli and Wilson, 2011). The new measure is able to capture actual trade flows rather than potential trade flows.

\footnotetext{
${ }^{2}$ A trade openness index should capture two dimensions: the share of a country's trade in its income, and the country's interaction and interconnectedness with the rest of the world (see Squalli and Wilson, 2011). Following Squalli and Wilson (2011), we define an open economy "as one that exhibits a relatively high share of trade to overall economic activity and substantial interaction and interconnectedness with the rest of the world" (p. 1747). That is, an open economy should trade intensively and should contribute substantially to global trade.
} 


\section{Construction of the Trade Openness Measures, Data and Empirical Model}

\section{Construction of the Trade Openness Measures}

The definition of trade openness has differed from one author to the other. Krueger (1978) understands an open economy to be the one which promotes favourable exportoriented policies. Anderson and Neary (1992) understand trade openness to mean the degree of distortion of an economy attributable to tariff and nontariff barriers. To Pritchett (1996), trade openness measures a country's trade intensity (see, also, Leamer, 1988). Harrison (1996) underscores the role of the neutrality of the incentives between the savings from import substitution and earnings from exports.

From these definitions, two distinct measures of trade openness emerge: (i) policyoriented measures and (ii) outcome-oriented measures. Several policy-oriented measures of trade openness have been developed in the literature (see Lee et al., 2004). Edwards (1998) proposes nine policy-oriented measures of trade openness in his paper. However, the problem with the policy-oriented measures is that they are subjective and therefore vary considerably from one author to the other. Due to this limitation, majority of the empirical studies have utilized the outcome-oriented measures of trade openness (see, for instance, Leamer, 1988; Dollar and Kraay, 2003; Yanikkaya, 2003; Alcalá and Ciccone, 2004; Awokuse, 2007; Cavallo and Frankel, 2008; Chang et al., 2009; Frankel, 2009). The key strength of the outcome-oriented measures is that they can be easily constructed using actual data compiled by recognized institutions such as the World Bank and the IMF.

This paper uses five outcome-oriented measures of trade openness for the empirical analysis. Three are already standard in the literature, while two are newly advanced measures. The three standard measures of trade openness have been utilized extensively, and are summarized in Table 1.

Table 1: Standard Measures of Trade Openness

\begin{tabular}{ll} 
Measure & Definition \\
\hline$(\mathrm{X}+\mathrm{M})_{\mathrm{i}} / \mathrm{GDP}_{\mathrm{i}}$ & $\begin{array}{l}\text { Trade intensity ratio or share (TS), measured as } \\
\text { the sum of exports and imports divided by country } \\
\text { i's GDP (see Leamer, 1988; Chang et al., 2009). }\end{array}$ \\
$\begin{array}{l}\text { Adjusted trade intensity ratio or share, which is an } \\
\text { alternative measure for dealing with outliers as } \\
\text { first suggested by Cavallo and Frankel (2008) and } \\
\text { Frankel (2009). }\end{array}$ \\
$\begin{array}{ll}\text { Real trade intensity ratio or share. The denomina- } \\
\text { tor is purchasing power parity adjusted GDP (real } \\
\text { GDP), as in Alcalá and Ciccone (2004). }\end{array}$ \\
\hline $\mathrm{X}+\mathrm{M})_{\mathrm{i}} / \mathrm{rGDP}_{\mathrm{i}}$ &
\end{tabular}

Note: $X=$ export, $M=$ import, $r G D P=$ purchasing power parity adjusted $G D P$.

Squalli and Wilson (2011) argue that the three outcome-oriented measures of trade openness in Table 1 may only capture one dimension of trade openness. That is, the three measures would only reflect a country's share in world trade. They fail to capture 
a country's benefits as a result of its interaction and interconnectedness with other countries in the world. In their view, Squalli and Wilson (2011) argue that a good outcomeoriented measure of trade openness should capture a country's share of trade, interaction and interconnectedness with others. An open economy would therefore show relatively high trade intensity and contribute significantly to world trade. They contend that "the importance of these two dimensions lies in the ability to focus on actual trade flows rather than potential trade flows, as captured by lax or liberal trade policies as well as other relevant socioeconomic, geographic and demographic factors" (Squalli and Wilson, 2011, p. 1747).

This paper enhances the three measures above by constructing two additional measures of trade openness following Squalli and Wilson (2011). However, our approach differs slightly from theirs because we use panel data, while they use cross-sectional data. The first measure of trade openness, the world trade share (WTS), captures a country's relative contribution to the total world trade. The second combines the first and the simple trade intensity ratio $\left[(X+M)_{i} / G D P_{i}\right]$ - which captures a country's share of trade to overall economic activity. The second measure is called the composite trade share (CTS). The first measure is calculated as

$$
W T S_{i}=\frac{(X+M)_{i}}{\sum_{j=1}^{n}(X+M)_{j}}
$$

where $j$ is a set of countries $\{1, \ldots, \mathrm{n}\}, i$ is a given country which belongs to $j, X$ and $M$ denote, respectively, export and import. By construction, WTS cannot exceed 0.5 because no country's import and export can exceed the combined total of the rest of the world (see Squalli and Wilson, 2011, p. 1754).

To calculate the second measure of trade openness (CTS), suppose that $D_{r}$ is a distance ratio which measures the deviation of WTS from its mean (i.e. the mean of all countries' WTS, denoted by $\overline{W T S}$ ). Then by the definition of the "openness frontier", we have that

$$
D_{r}=\frac{W T S_{i}}{\overline{W T S}}-1
$$

where $D_{r}<0$ when $W T S_{i}<\overline{W T S}$ and $D_{r}>0$ when $W T S_{i}>\overline{W T S}$. It follows that $C T S$ can be obtained as a product of $D_{r}$ and $T S$ as

$$
C T S_{i}=\left(1+D_{r}\right) T S_{i}
$$

Replacing $D_{r}$ in Eq. (3) with Eq. (2) and manipulating the resulting equation produces the following ${ }^{3}$

\footnotetext{
${ }^{3}$ See Squalli and Wilson (2011, p. 1758) for details.
} 


$$
C T S_{i}=\frac{(X+M)_{i}}{\frac{1}{n} \sum_{j=1}^{n}(X+M)_{j}} \frac{(X+M)_{i}}{G D P_{i}}
$$

CTS can be understood to mean TS adjusted by the proportion of a country's trade relative to the average world trade. Hence, $n W T S_{i}>1$ for a country that is a major contributor to world trade and its trade exceeds the world average. This causes an upward adjustment of $T S_{i}$. This is true, conversely. CTS penalizes smaller countries, while TS penalizes larger countries (see Squalli and Wilson, 2011).

\section{Data}

Table 2 shows the definitions of the variables used in the paper as well as their sources. Our dependent variable is real GDP per capita growth, which has also been used in studies such as Harrison (1996), Frankel and Romer (1999), Miller and Upadhyay (2000), Greenaway et al. (2002), Dollar and Kraay (2003, 2004), Yanikkaya (2003), Schneider (2005), Nannicini and Billmeier (2011), among others. Initial real GDP per capita is used an independent variable to capture convergence (see Yanikkaya, 2003). The variable of interest is trade openness. The measures used for trade openness are described above. The control variables are labour, capital, government consumption, and private credit. At least one of these variables has been included in studies such as Levine and Renelt (1992), Sachs and Warner (1995), Harrison (1996), Edwards (1998), Miller and Upadhyay (2000), Yanikkaya (2003), Awukose (2007), Wacziarg and Welch (2008), among others. Our data covers seventeen (17) countries ${ }^{4}$ over the period 1994 to 2014. Because observations are missing for some countries in some years, our dataset is unbalanced.

\section{Empirical Model}

To examine the importance of trade openness in growth within the CEE countries, we follow the literature closely by specifying the following empirical model

$g_{i t}=F\left(y_{i t-1}, l_{i t}, k_{i t}, x_{i t} ; z_{i t}\right)$

where $g_{i t}, y_{i t-1}, l_{i t}, k_{i t}, x_{i t}$ are the logarithms of real GDP per capita growth, initial real GDP per capita, labour, capital, and trade openness, respectively. $z_{i t}$ is a vector of control variables - they are government consumption and private credit.

\footnotetext{
${ }^{4}$ These countries are Albania, Bosnia and Herzegovina, Bulgaria, Croatia, Czech Republic, Estonia, Georgia, Hungary, Latvia, Lithuania, Macedonia FYR, Montenegro, Poland, Romania, Serbia, Slovak Republic, and Slovenia.
} 
Table 2: List of Variables and Sources

\begin{tabular}{|c|c|c|}
\hline Variable & Name & Source \\
\hline Growth & $\begin{array}{l}\text { GDP per capita growth (annu- } \\
\text { al \%) }\end{array}$ & $\begin{array}{l}\text { World Bank national accounts data, and OECD } \\
\text { National Accounts data files. }\end{array}$ \\
\hline GDP & $\begin{array}{l}\text { GDP per capita (constant } 2005 \\
\text { US\$) }\end{array}$ & $\begin{array}{l}\text { World Bank national accounts data, and OECD } \\
\text { National Accounts data files. }\end{array}$ \\
\hline LAB & $\begin{array}{l}\text { Labor force participation rate, } \\
\text { total (\% of total population ages } \\
15-64) \text { (modeled ILO estimate) }\end{array}$ & $\begin{array}{l}\text { International Labour Organization, Key Indicators of } \\
\text { the Labour Market database. }\end{array}$ \\
\hline CAP & $\begin{array}{l}\text { Gross fixed capital formation (\% } \\
\text { of GDP) }\end{array}$ & $\begin{array}{l}\text { World Bank national accounts data, and OECD } \\
\text { National Accounts data files. }\end{array}$ \\
\hline GCON & $\begin{array}{l}\text { General government final } \\
\text { consumption expenditure }(\% \text { of } \\
\text { GDP) }\end{array}$ & $\begin{array}{l}\text { World Bank national accounts data, and OECD } \\
\text { National Accounts data files. }\end{array}$ \\
\hline PRIVY & $\begin{array}{l}\text { Domestic credit to private sector } \\
\text { (\% of GDP) }\end{array}$ & $\begin{array}{l}\text { International Monetary Fund, International Financial } \\
\text { Statistics and data files, and World Bank and OECD } \\
\text { GDP estimates. }\end{array}$ \\
\hline$x$ & $\begin{array}{l}\text { Exports of goods and services } \\
\text { (constant } 2005 \text { US\$) }\end{array}$ & $\begin{array}{l}\text { World Bank national accounts data, and OECD } \\
\text { National Accounts data files. }\end{array}$ \\
\hline X_current & $\begin{array}{l}\text { Exports of goods and services } \\
\text { (BoP, current US\$) }\end{array}$ & $\begin{array}{l}\text { International Monetary Fund, Balance of Payments } \\
\text { Statistics Yearbook and data files. }\end{array}$ \\
\hline M_current & $\begin{array}{l}\text { Imports of goods and services } \\
(\text { BoP, current US\$) }\end{array}$ & $\begin{array}{l}\text { International Monetary Fund, Balance of Payments } \\
\text { Statistics Yearbook and data files. }\end{array}$ \\
\hline M & $\begin{array}{l}\text { Imports of goods and services } \\
\text { (constant } 2005 \text { US\$) }\end{array}$ & $\begin{array}{l}\text { World Bank national accounts data, and OECD } \\
\text { National Accounts data files. }\end{array}$ \\
\hline GDP_current & GDP (current US\$) & $\begin{array}{l}\text { World Bank national accounts data, and OECD } \\
\text { National Accounts data files. }\end{array}$ \\
\hline GDP_constant & GDP (constant 2005 US\$) & $\begin{array}{l}\text { World Bank national accounts data, and OECD } \\
\text { National Accounts data files. }\end{array}$ \\
\hline TS_WDI & Trade ( $\%$ of GDP) & $\begin{array}{l}\text { World Bank national accounts data, and OECD } \\
\text { National Accounts data files. }\end{array}$ \\
\hline TS_0 & Adjusted Trade Share & $\begin{array}{l}\text { Calculated (as in Table 1) using data from World } \\
\text { Bank national accounts data, and OECD National } \\
\text { Accounts data files. }\end{array}$ \\
\hline TS_AC & $\begin{array}{l}\text { Trade Share using Alcalá } \\
\text { and Ciccone (2004) method }\end{array}$ & $\begin{array}{l}\text { Calculated (as in Table 1) using data from World } \\
\text { Bank national accounts data, and OECD National } \\
\text { Accounts data files. }\end{array}$ \\
\hline WTS & World Trade Share & $\begin{array}{l}\text { Calculated as in Eq. (1) using data from World Bank } \\
\text { national accounts data, and OECD National Ac- } \\
\text { counts data files. }\end{array}$ \\
\hline CTS & Composite Trade Share & $\begin{array}{l}\text { Calculated as in Eq. (4) using data from World Bank } \\
\text { national accounts data, and OECD National Ac- } \\
\text { counts data files. }\end{array}$ \\
\hline
\end{tabular}

Note: $X, X_{-}$current, $M, M_{-}$current, GDP_current, GDP_constant, and TS were used in calculating the trade openness measures discussed above. 
In typical cross-sectional studies, variables such as land-lock, distance equator (see Dollar and Kraay, 2003), and land area (see Frankel and Romer, 1999; Squalli and Wilson, 2011) are used as controls. These variables are time invariant and may not shed additional insight in our case. Therefore, they do not appear in Eq. (5). Our control variables are similar to those utilized in studies such as Sachs and Warner (1995), Harrison (1996), Yanikkaya (2003), and Wacziarg and Welch (2008).

\section{Results}

This section presents the results of our empirical estimations. First, we report the pairwise correlations of the trade openness measures and real GDP per capita, and then the estimates of the simplified model. Here only the trade openness measures enter into the model as an independent variable. Next, we report and discuss the results of the extended model. This model contains, in addition to the trade openness measures, labour, capital, government consumption, and private credit as the independent variables. The literature finds two countries - Croatia and Estonia - to be always closed. Hence, we dropped them from the sample to see whether the results obtained using the extended model still holds. Finally, we present a sensitivity analysis of our results using the two-step system GMM estimator.

\section{Pairwise Correlations of the Trade Openness and Growth}

Table 3 shows the pairwise correlations of trade openness and growth. The first column shows the correlation between growth and the various measures of trade openness. The remaining columns show the correlations among the various measures of trade openness. The top panel shows the estimated correlation coefficients for the full sample, while the bottom column shows the estimated correlation coefficients for the sample which excludes two historically closed economies - Croatia and Estonia. In both samples the correlation between growth and the measures of trade openness is positive and (in most cases) statistically significant. This is consistent with majority of the existing studies, which find growth to correlate positively with trade openness (see, for instance, Yanikkaya, 2003; Wacziarg and Welch, 2008). There exists a positive and statistically significant correlation among lnTS_WDI, lnTS_AC, $\operatorname{lnWTS}$, and lnCTS. The notable exception is the negative and statistically significant correlation between InTS_O and the other measures of trade openness. Also, the correlation between $\operatorname{lnTS}$ _AC and lnWTS is insignificant, though positive. Unlike Squalli and Wilson (2011) who find the correlation between lnTS_WDI and lnWTS to be negative, we find it to be positive. The source of this difference could stem from the fact that they utilize cross-sectional data, while we utilize panel data. Noises introduced by time variation and aggregation may drive our result. A careful look at the results indicates that the measures of trade openness show a strong within group correlation and a weak across group correlation. That is, the correlations among similar measures of trade openness appear to be stronger than those of dissimilar measures. For example, the correlation between $\operatorname{lnCTS}$ and $\ln \mathrm{WTS}$ is stronger than say the one between lnCTS and lnTS_WDI. 
Table 3: Pairwise Correlation of real GDP per capita growth and Trade Openness

All Countries

\begin{tabular}{|c|c|c|c|c|c|c|}
\hline & InGrowth & InTS_WDI & InTS_0 & InTS_AC & InWTS & $\operatorname{lnCTS}$ \\
\hline InGrowth & 1.000 & & & & & \\
\hline InTS_WDI & $0.117^{* *}$ & 1.000 & & & & \\
\hline InTS_O & $0.498^{* *}$ & $-0.881^{* *}$ & 1.000 & & & \\
\hline InTS_AC & $0.207^{* *}$ & $0.806^{* *}$ & $-0.714^{* *}$ & 1.000 & & \\
\hline InWTS & $0.125^{\star *}$ & $0.195^{\star \star}$ & $-0.223^{* *}$ & 0.0803 & 1.000 & \\
\hline InCTS & $0.483^{* *}$ & $0.425^{\star *}$ & $-0.422^{* *}$ & $0.272^{* *}$ & $0.971^{* *}$ & 1.000 \\
\hline \multicolumn{7}{|c|}{ All Minus Historically Closed Countries } \\
\hline & InGrowth & InTS_WDI & InTS_0 & InTS_AC & InWTS & $\operatorname{lnCTS}$ \\
\hline InGrowth & 1.000 & & & & & \\
\hline InTS_WDI & $0.234^{* *}$ & 1.000 & & & & \\
\hline InTS_O & $0.427^{* *}$ & $-0.871^{* *}$ & 1.000 & & & \\
\hline InTS_AC & $0.384^{* *}$ & $0.814^{* *}$ & $-0.713^{* *}$ & 1.000 & & \\
\hline InWTS & $0.432^{* *}$ & $0.238^{* *}$ & $-0.277^{\star *}$ & 0.107 & 1.000 & \\
\hline $\operatorname{lnCTS}$ & $0.404^{* *}$ & $0.449^{* *}$ & $-0.455^{\star *}$ & $0.286^{* *}$ & $0.975^{\star *}$ & 1.000 \\
\hline
\end{tabular}

Notes: ** denotes significance at 5\%. The significance level is Bonferroni-adjusted. Pairwise correlations are based on Pearson (1896). In denotes natural logarithm.

\section{The Role of Trade Openness in Growth in a Simplified Model}

Following Harrison (1996), and Wacziarg and Welch (2008), we estimate Eq. (5) using the fixed-effects (within-effects) estimator. Table 4 shows the results obtained from the simplified model. We regressed the natural logarithm of real GDP per capita growth on the natural logarithm of initial real GDP per capita, and the natural logarithm of each one of the trade openness measures discussed in section 3. Note that TS is an indicator of trade openness. The coefficients of the trade openness measures are significant with positive signs and consistent with majority of the existing literature. Among the five measures of trade openness, the simple measure of trade openness, namely, InTS_WDI, has the highest coefficient, while lnWTS has the lowest coefficient. A limitation of these results is that the model is underspecified, since key drivers of the economy are absent. This limitation is overcome in what follows. 
Table 4: Results of the Simplified Model

\begin{tabular}{llllll} 
Variable & InTS_WDI & InTS_O & $\begin{array}{l}\text { InTS_AC } \\
\text { Coefficients }\end{array}$ & InWTS & InCTS \\
\hline InGDP(-1) & $-1.367^{* *}$ & $-1.347^{*}$ & $-1.462^{* *}$ & $-1.692^{* * *}$ & $-1.528^{* *}$ \\
& $(-2.140)$ & $(-1.990)$ & $(-2.400)$ & $(-3.880)$ & $(-2.910)$ \\
TS & $0.760^{* * *}$ & $0.501^{* * *}$ & $0.446^{* * *}$ & $0.088^{* *}$ & $0.304^{* * *}$ \\
& $(6.810)$ & $(5.640)$ & $(11.320)$ & $(2.640)$ & $(3.600)$ \\
Constant & $5.154^{* * *}$ & $10.533^{* * *}$ & $6.613^{* * *}$ & $8.504^{* * *}$ & $6.034^{* * *}$ \\
& $(10.190)$ & $(30.730)$ & $(37.700)$ & $(58.600)$ & $(8.470)$
\end{tabular}

Diagnostics

\begin{tabular}{llllll}
\hline F-statistic & 46.340 & 31.860 & 128.080 & 11.420 & 12.930 \\
P-value & 0.000 & 0.000 & 0.000 & 0.008 & 0.002 \\
$\mathrm{R}^{2}$ & & & & & \\
Within & 0.350 & 0.230 & 0.690 & 0.005 & 0.156 \\
Between & 0.273 & 0.303 & 0.236 & 0.436 & 0.524 \\
Overall & 0.265 & 0.248 & 0.234 & 0.365 & 0.467 \\
& & & & & \\
Time dummies & yes & yes & yes & yes & yes \\
Country dummies & yes & yes & yes & yes & yes \\
Observations & 292 & 292 & 292 & 292 & 292
\end{tabular}

Notes: Robust $t$-statistics are in the parenthesis. $* *$ and $* * *$ denote, respectively, significance at $5 \%$ and $10 \%$ levels. TS is an indicator of trade openness. Dependent variable is the log of real GDP per capita growth.

\section{Adding More Determinants}

Table 5 shows the results obtained for the extended model. Here we introduce labour, capital, government consumption, and private credit as control variables. In theory, these are important drivers of the economy and should therefore be included in our model. The results obtained here are not entirely different from the ones obtained using the simplified model, suggesting that omitted variable bias do not drive our results. All the measures of trade openness are significant and have positive signs, which are consistent with majority of the literature (see, for example, Frankel and Romer, 1999; Dollar and Kraay, 2003; Wacziarg and Welch, 2008; Squalli and Wilson, 2011). This suggests that trade openness enhances growth within the CEE countries. Capital is also found to be playing a significant role in growth. Higher capital stock and labour appear to exert positive impact on growth, although the latter is only statistically significant in the lnTS_WDI and lnCTS model. Private credit is associated with growth in a positive 
fashion, which is consistent with the literature. The role of government consumption is ambiguous as we find it to exert either negative or positive impact on growth.

Table 5: Results of the Model with Controls

\begin{tabular}{llllll} 
Variable & TS_WDI & InTS_O & $\begin{array}{l}\text { InTS_AC } \\
\text { Coefficient }\end{array}$ & InWTS & InCTS \\
\hline InGDP(-1) & $-1.158^{*}$ & $-1.194^{*}$ & $-1.438^{* *}$ & $-1.679^{* * *}$ & $-1.444^{* * *}$ \\
& $(-1.940)$ & $(-1.990)$ & $(-2.540)$ & $(-4.870)$ & $(-3.250)$ \\
TS & $0.743^{* *}$ & $0.555^{* * *}$ & $0.429^{* * *}$ & $0.183^{* *}$ & $0.334^{* * *}$ \\
InLAB & $(5.550)$ & $(7.370)$ & $(9.260)$ & $(2.450)$ & $(3.930)$ \\
& $1.859^{*}$ & 0.460 & 0.434 & 0.167 & $0.215^{* *}$ \\
InCAP & $(2.070)$ & $(0.460)$ & $(0.740)$ & $(1.240)$ & $(2.220)$ \\
& $0.409^{* *}$ & $0.471^{* * *}$ & $0.288^{* * *}$ & $0.342^{* * *}$ & $0.398^{* * *}$ \\
InGCON & $(7.680)$ & $(8.830)$ & $(4.810)$ & $(5.330)$ & $(6.450)$ \\
& -0.010 & 0.047 & 0.056 & -0.125 & -0.074 \\
InPRIVY & $(-0.030)$ & $(0.150)$ & $(0.300)$ & $(-0.320)$ & $(-0.220)$ \\
& 0.070 & $0.120^{*}$ & 0.025 & $0.160^{*}$ & 0.114 \\
Constant & $(1.250)$ & $(2.120)$ & $(0.860)$ & $(2.060)$ & $(1.730)$ \\
& $4.008^{* *}$ & 6.838 & 3.751 & 0.188 & $4.644^{* * *}$ \\
& $(2.950)$ & $(1.540)$ & $(1.330)$ & $(0.030)$ & $(4.020)$
\end{tabular}

Diagnostics

\begin{tabular}{llllll}
\hline F-statistic & 41.660 & 27.736 & 29.390 & 16.850 & 41.070 \\
P-value & 0.000 & 0.000 & 0.000 & 0.000 & 0.000 \\
$\mathrm{R}^{2}$ & & & & & \\
Within & 0.553 & 0.529 & 0.771 & 0.298 & 0.433 \\
Between & 0.487 & 0.547 & 0.446 & 0.781 & 0.783 \\
Overall & 0.479 & 0.481 & 0.373 & 0.661 & 0.727 \\
& & & & & \\
Time dummies & yes & yes & yes & yes & yes \\
Country dummies & yes & yes & yes & yes & yes \\
Observations & 275 & 275 & 275 & 275 & 275 \\
\hline
\end{tabular}

Notes: Robust $t$-statistics are in the parenthesis. $*, * *$ and $* * *$ denote, respectively, significance at 1\%, 5\% and $10 \%$ levels. TS is an indicator of trade openness. Dependent variable is the log of real GDP per capita growth. 


\section{What if Historically Closed Economies are dropped?}

The results obtained thus far are based on the assumption that all the CEE countries are open. However, the empirical literature documents that two countries - Croatia and Estonia - are always closed (see Wacziarg and Welch, 2003, 2008; Nannicini and Billmeier, 2011). Do we obtain different results, if we drop these two 'closed' countries from our sample? Table 6 shows the results when we dropped Croatia and Estonia from our sample. The results are identical to the ones presented in Table 5. However, there is a slight difference between the coefficient estimates of $\operatorname{lnWTS}$ in the two tables. In Table 5, the coefficient estimate of lnWTS is smaller (0.183) relative to the one in Table 6 (0.222). This shows that dropping the two historically 'closed' countries has impact on our estimates. Generally, InTS_WDI has remained the highest coefficient, while lnWTS is the lowest. Importantly, all coefficients of trade openness are positive and significant, indicating that open CEE economies have higher growth, other factors remaining the same.

\section{Sensitivity Analysis of the Results}

A problem that may still arise thereby throwing these results into question is the presence of endogeneity. It is not farfetched to think that countries may actually open up as a consequence of excess production. This is because if countries expand faster than the local markets to trade their products, they would seek external markets to do so. In this sense, countries may open up just to gain access to foreign markets in order to trade their surpluses. So, what appears to be trade openness driving productivity may actually be reverse causality, whereby trade openness is productivity driven. In addition, the measures of trade openness that we use in this paper may be correlated with other unobserved country characteristics. This may create identification problems and potentially biased estimators (see Cavallo and Frankel, 2008, p. 1435). Also, in models as ours, there are potential omitted variables that are likely to be correlated with both trade openness and real GDP per capita growth, thereby rendering the estimates biased. Moreover, the presence of the initial real GDP per capita (i.e. the lag of real GDP per capita) in the model introduces dynamic panel bias (see Roodman, 2009a,b).

The generalized method of moments (GMM) technique, proposed in Arellano and Bond (1991), Arellano and Bover (1995), and Blundell and Bond (1998), offers a suitable strategy to surmount the endogeneity problem. However, care must be taken in order not to misuse this technique. Roodman (2009a,b) has recommended that only FE estimations should be reported in situations where $\mathrm{T}>\mathrm{N}$ (i.e. the time dimension is greater than the cross-sectional dimension). According to Roodman (2009b), the dynamic panel bias tends to be insignificant using FE estimators, while the number of instruments explodes using GMM estimator, when $\mathrm{T}>\mathrm{N}$. He also notes that when $\mathrm{N}$ is small, the cluster-robust standard errors and the Arellano-Bond autocorrelation test are not reliable (see p. 128). Hence, in our case GMM may not be suitable. However, to clear any doubt about our results, we report the GMM results. The choice of instruments has important implications for GMM results. For example, Windmeijer (2005) observes that when instrument counts are lowered mean bias of parameters are lowered as well. In a similar vein, Roodman (2009a) notes that increases in the instrument count can lead to overestimation of parameters. Moreover, León-González and Montolio (2015) find that models which involve nearer lags as instruments have larger posterior probability. In spite of 
the importance of instrument selection, there is no clear guidance on the optimal number of instruments to choose, when controlling for endogeneity in regressions, as argued by León-González and Vinagayathasan (2015).

Table 6: Results for Historically Opened CEE Countries

\begin{tabular}{llllll} 
Variable & TS_WDI & InTS_O & $\begin{array}{l}\text { InTS_AC } \\
\text { Coefficient }\end{array}$ & InWTS & InCTS \\
\hline LnGDP(-1) & $-1.463^{* * *}$ & $-1.518^{* * *}$ & $-1.704^{* * *}$ & $-1.845^{* * *}$ & $-1.680^{* * *}$ \\
& $(-3.540)$ & $(-3.760)$ & $(-4.140)$ & $(-6.670)$ & $(-5.030)$ \\
TS & $0.699^{* * *}$ & $0.557^{* * *}$ & $0.412^{* * *}$ & $0.222^{* *}$ & $0.334^{* * *}$ \\
& $(4.290)$ & $(6.020)$ & $(7.250)$ & $(2.650)$ & $(3.230)$ \\
InLAB & 1.611 & $0.227^{* *}$ & $0.520^{* *}$ & 1.276 & $1.882^{*}$ \\
& $(1.700)$ & $(2.230)$ & $(2.800)$ & $(1.020)$ & $(1.980)$ \\
InCAP & $0.369^{* * *}$ & $0.429^{* * *}$ & $0.270^{* * *}$ & $0.292^{* * *}$ & $0.356^{* * *}$ \\
& $(7.860)$ & $(7.770)$ & $(4.340)$ & $(5.570)$ & $(6.010)$ \\
InGCON & 0.088 & 0.166 & 0.127 & 0.007 & 0.062 \\
& $(0.360)$ & $(0.740)$ & $(0.800)$ & $(0.020)$ & $(0.240)$ \\
InPRIVY & $0.109^{* *}$ & $0.159^{* *}$ & $0.044^{*}$ & $0.207^{* *}$ & $0.151^{*}$ \\
& $(2.760)$ & $(2.850)$ & $(2.14)$ & $(2.64)$ & $(2.11)$ \\
Constant & -3.103 & $7.426^{* *}$ & 3.199 & $1.325^{* *}$ & -3.965 \\
& $(-0.700)$ & $(2.670)$ & $(1.03)$ & $(2.230)$ & $(-0.870)$
\end{tabular}

Diagnostics

\begin{tabular}{llllll}
\hline F-statistic & 34.550 & 21.587 & 32.480 & 21.74 & 28.980 \\
P-value & 0.000 & 0.000 & 0.000 & 0.000 & 0.000 \\
$\mathrm{R}^{2}$ & & & & & \\
Within & 0.606 & 0.609 & 0.776 & 0.386 & 0.513 \\
Between & 0.607 & 0.599 & 0.558 & 0.780 & 0.804 \\
Overall & 0.556 & 0.523 & 0.412 & 0.694 & 0.758 \\
Time dummies & yes & yes & yes & yes & yes \\
Country dummies & yes & yes & yes & yes & yes \\
Observations & 243 & 243 & 243 & 243 & 243
\end{tabular}

Notes: Robust t-statistics are in the parenthesis. *, ** and *** denote, respectively, significance at 1\%, 5\% and $10 \%$ levels. TS is an indicator of trade openness. Dependent variable is the log of real GDP per capita growth. 
We apply the two-step system GMM estimator with the Windmeijer (2005) corrected cluster-robust errors to overcome the possibility that trade openness is endogenous. ${ }^{5} \mathrm{We}$ use the forward orthogonal deviations to transform the variables due to the unbalanced nature of our dataset. The alternative transformation, first-difference transformation, may increase the gaps in our dataset since it is already unbalanced (see Arellano and Bover, 1995). Following Roodman (2009a,b), we experiment with different specifications of our model by collapsing the instrument matrices, by controlling the a priori estimate of the covariance matrices of the idiosyncratic errors and by reducing the instrument counts using the principal component analysis technique as discussed in Mehrhoff (2009), Bai and $\mathrm{Ng}$ (2010), and Kapetanios and Marcellino (2010). It turns out that we arrive at "empirically reasonable" results only after dropping the time dummies, treating trade openness and initial real GDP per capita as the only endogenous variables, and treating the other independent variables as strictly exogenous. These results are shown in Table 7 . This treatment is quite artificial, since in theory labour, capital, government consumption, and private credit are more likely to be predetermined than being strictly exogenous. Moreover, time fixed-effects if not filtered out from the error term may be correlated with initial real GDP per capita and trade openness. In fact, the time dummies are required as strictly exogenous variables in order to force the assumption of no correlation across individuals in the idiosyncratic disturbances to hold (see Roodman, 2009b, p. 128). Therefore, dropping them seems unreasonable. In contrast, the other treatments, namely: (i) treating trade openness and initial real GDP per capita as endogenous, the other variables as predetermined, and time fixed-effects as strictly exogenous; and (ii) treating trade openness and initial real GDP per capita as endogenous, labour and capital as predetermined, and time fixed-effects, government consumption, and private credit as strictly exogenous tend to produce many instruments, overestimated coefficients, and perfect p-values for the tests of joint validity of instruments. ${ }^{6}$ The fact that we have to treat the variables in a rather unconventional way to produce reasonable results reinforces our earlier argument about the inappropriateness of the GMM techniques when $\mathrm{T}>\mathrm{N}$. When compared with the FE results above, the GMM results appear overestimated (see Table 7). However, the GMM results show that trade openness is positively associated with growth, which is consistent with the FE results. The coefficient estimates for trade openness are also significant in all cases except in the case of lnWTS.

\footnotetext{
${ }^{5}$ We favour system GMM because difference GMM is vulnerable to the problem of weak instruments (see Staiger and Stock, 1997; Roodman, 2009a).

${ }^{6}$ These results are preserved due to space consideration. They are readily available upon request.
} 
Table 7: Two-step system GMM results

\begin{tabular}{|c|c|c|c|c|c|}
\hline Variable & InTS_WDI & InTS_O & InTS_AC & InWTS & InCTS \\
\hline \multirow[t]{2}{*}{$\ln G D P(-1)$} & $-2.983^{* * *}$ & $-1.425^{\star *}$ & $-1.433^{* *}$ & $-.757^{* *}$ & $-1.004^{*}$ \\
\hline & $(-5.640)$ & $(-2.890)$ & $(-2.440)$ & $(-2.420)$ & $(-1.907)$ \\
\hline \multirow[t]{2}{*}{ TS } & $0.963^{\text {*** }}$ & $0.622^{* * *}$ & $0.396^{\star * *}$ & $0.483^{*}$ & $0.779^{* * *}$ \\
\hline & $(3.617)$ & (3.332) & (3.587) & $(1.962)$ & $(3.198)$ \\
\hline \multirow[t]{2}{*}{$\ln L A B$} & $3.049^{*}$ & $2.948^{*}$ & $3.562^{\star * *}$ & 3.397 & 3.214 \\
\hline & $(2.096)$ & $(1.959)$ & $(4.016)$ & $(0.678)$ & $(1.007)$ \\
\hline \multirow[t]{2}{*}{$\operatorname{InCAP}$} & $0.557^{\star * *}$ & $0.634^{* * *}$ & $0.500^{\star * *}$ & 0.552 & 0.497 \\
\hline & $(6.277)$ & $(7.520)$ & $(5.416)$ & $(0.644)$ & $(0.913)$ \\
\hline \multirow[t]{2}{*}{ InGCON } & $0.930^{* * *}$ & $1.131^{* * *}$ & $1.169^{* * *}$ & -1.174 & -1.407 \\
\hline & $(3.476)$ & $(4.836)$ & $(4.029)$ & $(-0.509)$ & $(-1.159)$ \\
\hline \multirow[t]{2}{*}{ InPRIVY } & $0.178^{\star *}$ & $0.238^{* * *}$ & 0.088 & 0.163 & 0.077 \\
\hline & $(2.833)$ & $(4.107)$ & $(1.061)$ & $(0.592)$ & $(0.494)$ \\
\hline \multirow[t]{2}{*}{ Constant } & $-13.542^{* *}$ & -7.390 & $-13.302^{* *}$ & $-5.495^{\star \star}$ & -9.259 \\
\hline & $(-2.428)$ & $(-1.053)$ & $(-3.634)$ & $(-2.197)$ & $(-0.565)$ \\
\hline Observations & 275 & 275 & 275 & 275 & 275 \\
\hline Number of Instruments & 10 & 10 & 10 & 10 & 10 \\
\hline $\begin{array}{l}\text { Arellano-Bond test for } \\
A R(2) \text { in differences ( } p \text { - } \\
\text { value) }\end{array}$ & 0.384 & 0.579 & 0.222 & 0.334 & 0.736 \\
\hline $\begin{array}{l}\text { Sargan test of joint } \\
\text { validity of instruments } \\
\text { (p-value) }\end{array}$ & 0.415 & 0.160 & 0.389 & 0.336 & 0.247 \\
\hline $\begin{array}{l}\text { Hansen test of joint } \\
\text { validity of instruments } \\
\text { (p-value) }\end{array}$ & 0.466 & 0.292 & 0.205 & 0.389 & 0.265 \\
\hline $\begin{array}{l}\text { Portion of variance } \\
\text { explained by the com- } \\
\text { ponents }\end{array}$ & 0.890 & 0.887 & 0.839 & 0.853 & 0.886 \\
\hline $\begin{array}{l}\text { Kaiser-Meyer-Olkin } \\
\text { measure of sampling } \\
\text { adequacy }\end{array}$ & 0.885 & 0.880 & 0.866 & 0.865 & 0.842 \\
\hline
\end{tabular}

Notes: All regressions are two-step system GMM, time dummies are not incorporated in regressions, Windmeijer (2005) corrected cluster-robust t-statistics are in the parenthesis. *, ** and *** denote, respectively, significance at 1\%, 5\% and 10\% levels. TS is an indicator of trade openness. Dependent variable is the log of real GDP per capita growth. 


\section{Conclusion}

The role of trade openness in economic activities has been at the forefront of economic debates. This paper adds to the literature by answering the question: Does trade openness matter for economic growth in the CEE countries? The CEE countries are particularly suitable because they have undertaken broad trade liberalization policies in the past two decades in order to open up their markets to external participants. Despite pursuing broad trade liberalization policies, few studies have assessed the impact of the resulting trade openness on growth in the CEE countries. In addition, we explored the existing literature and noted that majority of the studies have either utilized policy-oriented measures of trade openness which are mostly subjective, or they utilized outcomeoriented measures of trade openness which only capture the share of a country's trade in its GDP. Following a recent study, we constructed a new outcome-oriented measure of trade openness, which captures all dimensions of trade openness. Then, using this new measure of trade openness, we estimated fixed-effects regressions for a panel of $17 \mathrm{CEE}$ countries during the period $1994-2014$. We found trade openness to be a good predictor of growth within these countries. That is, increases in trade openness are associated with increases in growth. When compared with the simple outcome-oriented measures (i.e. measures which capture only a country's share of trade in GDP), the coefficient estimates of the new measure of trade openness appear to be smaller, revealing how the former may overestimate the impact of trade openness on growth. We then dropped two historically closed economies from the sample, leaving us with 15 open CEE countries. The results we obtained after dropping these two countries did not change significantly, suggesting that the two closed countries may not necessarily be driving our results. Our results do not immediately imply that policymakers in the CEE countries should necessarily pursue further liberalization policies to speed up growth. Instead, it shows that openness-oriented policies may be associated with growth within these countries. Given that we have not examined case-by-case bases of the impact of trade openness on growth in each one of the $17 \mathrm{CEE}$ countries, our results should be understood to reflect within country elasticities. Country-specific insights of the trade openness impact could be obtained by assessing the issue for each country in our sample. This should be the focus of future studies. Moreover, a better way we could have assessed the impact of trade openness on growth for these countries would have been to consider preliberalization and post-liberalization data. However, lack of data pre-1994 presented a major hurdle. Nevertheless, we could take comfort in our results because most existing empirical studies have shown similar results for outcome-oriented measures of trade openness.

Acknowledgements: Previous version of this paper was presented at the Department of Economics' seminar series, University of Pretoria. The author thanks, without implicating, Manoel Bittencourt, Martin Breitenbach, Matthew Clance, Roula Inglesi-Lotz, Andre Jordaan, Sin-Yu Ho, Mulatu Zerihun, and seminar participants for their helpful comments. The author also thanks Jan Jonáš and two anonymous reviewers for their helpful comments and suggestions which have improved this paper. All remaining shortcomings are regretfully the author's.

Disclosure statement: No potential conflict of interest was reported by the author. 


\section{References}

Acemoglu, D., Johnson, S., Robinson, J. and Thaicharoen, Y. (2003). Institutional causes, macroeconomic symptoms: Volatility, crises and growth. Journal of Monetary Economics, 5 (1), 49-123. DOI: 10.1016/S0304-3932(02)00208-8

Aizenman, J. and Noy, I. (2006). FDI and Trade-Two-Way Linkages? The Quarterly Review of Economics and Finance, 46(4), 317-37. DOI: 10.1016/i.qref.2006.02.004

Alcalá, F. and Ciccone, A. (2004). Trade and Productivity. Quarterly Journal of Economics, 119(2), 613-46. DOI: 10.1162/0033553041382139

Anderson, J. E. and Neary, J. P. (1992). Trade reform with quotas, partial rent retention, and tariffs. Econometrica, 60(1), 57-76. DOI: 10.2307/2951676

Arellano, M. and Bond, S. (1991). Some tests of specification for panel data: Monte Carlo evidence and an application to employment equations. Review of Economic Studies, 58(2), 277-297. DOI: $10.2307 / 2297968$

Arellano, M. and Bover, O. (1995). Another look at the instrumental variable estimation of error-components models. Journal of Econometrics, 68(1), 29-51. DOI: $\underline{10.1016 / 0304-4076(94) 01642-\mathrm{D}}$

Awokuse, T. O. (2007). Causality between exports, imports, and economic growth: Evidence from transition economies. Economics Letters, 94(3), 389-395. DOI: 10.1016/j.econlet.2006.08.025

Bai, J. and S. Ng. (2010). Instrumental variables estimation in a data rich environment. Econometric Theory. 26(6), 1577-1606. DOI: $10.1017 /$ S0266466609990727

Bhagwati, J. and Srinivasan, T. N. (2002). Trade and poverty in the poor countries. American Economic Review Papers and Proceedings, 92(2), 180-193.

Billmeier, A. and Nannicini, T. (2009). Trade openness and growth: pursuing empirical glasnost. IMF Economic Review, 56(3), 447-475.

Blundell, R. and Bond, S. (1998). Initial conditions and moment restrictions in dynamic panel data models. Journal of Econometrics, 87(1), 115-143. DOI: $10.1016 / \mathrm{S} 0304-$ $\underline{\text { 4076(98)00009-8 }}$

Cavallo, E.A. and Frankel, J.A. (2008). Does openness to trade make countries more vulnerable to sudden stops, or less? Using gravity to establish causality. Journal of International Money and Finance, 27(8), 1430-1452. DOI: 10.1016/j.jimonfin.2007.10.004

Chang, R., Kaltani, L. and Loayza, N. V. (2009). Openness can be good for growth: The role of policy complementarities. Journal of Development Economics, 90(1), 33-49. DOI: $10.1016 /$ j.jdeveco.2008.06.011

Chintrakarn, P. and Millimet, D. L. (2006). The Environmental Consequences of Trade: Evidence from Subnational Trade Flows. Journal of Environmental Economics and Management, 52(3), 430-53. DOI: 10.1016/j.jeem.2006.03.001 
Combes, J.-L., and Saadi-Sedik, T. (2006). How does trade openness influence budget deficits in developing countries? The Journal of Development Studies, 42(8), 1401-1416. DOI: $10.1080 / 00220380600930762$

Dollar, D. (1992). Outward-Oriented Developing Economies Really Do Grow More Rapidly: Evidence from 95 LDCs 1976-1985. Economic Development and Cultural Change, 40(3), 523-44.

Dollar, D. and Kraay, A. (2003). Institutions, trade, and growth. Journal of Monetary Economics, 50(1), 133-162. DOI: 10.1016/S0304-3932(02)00206-4

Dollar, D. and Kraay, A. (2004). Trade, Growth, and Poverty. Economic Journal, 114(493), F22-F49. DOI: 10.1111/j.0013-0133.2004.00186.x

Edwards, S. (1992). Trade Orientation, Distortions and Growth in Developing Countries. Journal of Development Economics, 39(1), 31-57. DOI: 10.1016/0304-3878(92)90056$\underline{\mathrm{F}}$

Edwards, S. (1993). Openness, Trade Liberalization, and Growth in Developing Countries. Journal of Economic Literature, 31(3), 1358-93.

Edwards, S. (1998). Openness, Productivity and Growth: What Do We Really Know? Economic Journal, 108(447), 383-98. DOI: 10.1111/1468-0297.00293

Estevadeordal, A. and Taylor, A. M. (2008). Is the Washington Consensus Dead? Growth, Openness, and the Great Liberalization, 1970s-2000s, NBER Working Paper No. 14264, National Bureau of Economic Research, Cambridge, MA.

Falvey, R., Foster, N. and Greenaway D. (2004). Imports, Exports, Knowledge Spillovers and Growth. Economics Letters, 85(2), 209-13. DOI: 10.1016/j.econlet.2004.04.007

Fatás, A., and Mihov, I. (2003). The case for restricting fiscal policy discretion. Quarterly Journal of Economics, 118(4), 1419-1447. DOI: 10.1162/003355303322552838

Frankel, J. A. (2009). Environmental Effects of International Trade. Faculty Research Working Paper Series No. RWP09-006 (Cambridge, MA: Harvard University).

Frankel, J. A. and D. Romer (1999). Does Trade Cause Growth? American Economic Review, 89(2), 379-99. DOI: 10.1257/aer.89.3.379

Frankel, J. A. and Rose, A. (2005). Is Trade Good or Bad for the Environment? Sorting out the Causality. The Review of Economics and Statistics, 87(1), 85-91.

Gavin, M. and Hausmann, R. (1996). Sources of macroeconomic volatility in developing economies. Mimeo, Inter-American Development Bank, Washington (DC) (1996).

Giavazzi, F. and Tabellini, G. (2005). Economic and political liberalizations. Journal of Monetary Economics, 52(7), 1297-1330. DOI: 10.1016/j.jmoneco.2005.05.002

Greenaway, D., Morgan, W., and Wright, P. (2002). Trade liberalisation and growth in developing countries. Journal of Development Economics, 67(1), 229-244. DOI: 10.1016/S0304-3878(01)00185-7 
Harrison, A. (1996). Openness and growth: A time-series, cross-country analysis for developing countries. Journal of Development Economics, 48(2), 419-447. DOI: 10.1016/0304-3878(95)00042-9

Helpman, E. and P. Krugman (1985). Market Structure and Foreign Trade (Cambridge, MA: MIT Press).

Kapetanios, G., M. Marcellino. (2010). Factor-GMM estimation with large sets of possibly weak instruments. Computational Statistics and Data Analysis, 54(11), 26552675. DOI: $10.1016 /$ j.csda.2010.04.008

Koren, M. and Tenreyro, S. (2007). Volatility and development. Quarterly Journal of Economics, 122 (1), 243-287. DOI: 10.1162/qjec.122.1.243

Krueger, A. O. (1978), Liberalization Attempts and Consequences (Cambridge: Ballinger).

Leamer, E. E. (1988). Measures of Openness," NBER Chapters, in: Trade Policy Issues and Empirical Analysis, 145-204. National Bureau of Economic Research.

Lee, H. Y., Ricci, L. A. and Rigobon, R. (2004). Once Again, Is Openness Good for Growth? Journal of Development Economics, 75(2), 451-472. DOI: 10.1016/j.jdeveco.2004.06.006

León-González, R., and Montolio, D. (2015). Endogeneity and panel data in growth regressions: A Bayesian model averaging approach. Journal of Macroeconomics, 46(C), 23-39. DOI: $\underline{10.1016 / \text { j.jmacro.2015.07.003 }}$

León-González, R. and Vinayagathasan, T. (2015). Robust determinants of growth in Asian developing economies: A Bayesian panel data model averaging approach. Journal of Asian Economics, 36(C), 34-46. DOI: 10.1016/j.asieco.2014.12.001

Levine, R., and Renelt, D. (1992). A Sensitivity Analysis of Cross-Country Growth Regressions. American Economic Review, 82(4), 942-963.

Li, K., Morck, R., Yang, F., and Yeung, B. (2004). Firm-Specific Variation and Openness in Emerging Markets. The Review of Economics and Statistics, 86(3), 658-69. DOI: $10.1162 / 0034653041811789$

Malik, A., and Temple, J.R.W. (2009). The geography of output volatility. Journal of Development Economics, 90 (2), 163-178. DOI: 10.1016/j.jdeveco.2008.10.003

Markusen, J. R., T. F. Rutherford and L. Hunter (1995). Trade Liberalisation in a Multinational dominated Industry. Journal of International Economics, 38(1), 95-117. DOI: $\underline{10.1016 / 0022-1996(94) 01339-T}$

Mehrhoff, J. (2009). A solution to the problem of too many instruments in dynamic panel data GMM. Discussion Paper Series 1. No 31/2009.

Miller, S. M. and Upadhyay, M. P. (2000). The effects of openness, trade orientation, and human capital on total factor productivity. Journal of Development Economics, 63(2), 399-423. DOI: 10.1016/S0304-3878(00)00112-7 
Montalbano, P. (2011). Trade Openness and Developing Countries' Vulnerability: Concepts, Misconceptions, and Directions for Research. World Development, 39(9), 14891502. DOI: $10.1016 /$ j.worlddev.2011.02.009

Nannicini, T. and Billmeier, A. (2011). Economies in transition: How important is trade openness for growth? Oxford Bulletin of Economics and Statistics, 73(3), 287-314. DOI: 10.1111/j.1468-0084.2010.00626.x

Neumayer, E. and Soysa, I. (2005). Trade Openness, Foreign Direct Investment and Child Labor. World Development, 33(1), 43-63. DOI: 10.1016/j.worlddev.2004.06.014

Pearson, K. (1896). Mathematical contributions to the theory of evolution-III. Regression, heredity, and panmixia. Philosophical Transactions of the Royal Society of London, Series A, 187, 253-318.

Pernia, E. M. and Quising, P. F. (2003). Trade Openness and Regional Development in a Developing Country. The Annals of Regional Science, 37(3), 391-406. DOI: $10.1007 / \mathrm{s} 00168-003-0160-\mathrm{y}$

Pritchett, L. (1996). Measuring Outward Orientation in the LDCs: Can It Be Done? Journal of Development Economics, 49(2), 309-55. DOI: 10.1016/03043878(95)00064-X

Pritchett, L. (2000). Understanding patterns of economic growth: searching for hills among plateaus, mountains, and plains. World Bank Economic Review, 14(2), 221-250. DOI: $10.1093 /$ wber/14.2.221

Razin, A., Sadka, E., and Coury, T. (2003). Trade openness, investment instability and terms-of-trade volatility. Journal of International Economics, 61(2), 285-306. DOI: 10.1016/S0022-1996(03)00014-X

Rodriguez, F., and Rodrik, D. (2001). Trade policy and economic growth: a skeptic's guide to the cross-national evidence. In NBER Macroeconomics Annual 2000, 15, (pp. 261-338). MIT Press.

Rodrik, D. (1999). Where did all the growth go? External shocks, social conflict, and growth collapses. Journal of Economic Growth, 4(4), 385-412. DOI: 10.1023/A:1009863208706

Romer, D. H. and Frankel, J. A. (1999). Does Trade Cause Growth? American Economic Review, 89(3), 379-399. DOI: 10.1257/aer.89.3.379

Roodman, D. (2009a). A Note on the Theme of Too Many Instruments. Oxford Bulletin of Economics and Statistics, 71(1), 135-158. DOI: 10.1111/j.1468-0084.2008.00542.x

Roodman, D. (2009b). How to do xtabond2: An introduction to difference and system GMM in Stata. Stata Journal, 9(1), 86-136.

Sachs, J. D., and Warner, A. (1995). Economic Reform and the Process of Global Integration. Brookings Papers on Economic Activity, 1995(1), 1-118. DOI: $\underline{10.2307 / 2534573}$ 
Schneider, P. H. (2005). International trade, economic growth and intellectual property rights: A panel data study of developed and developing countries. Journal of Development Economics, 78(2), 529-547. DOI: 10.1016/j.jdeveco.2004.09.001

Slaughter, M. J. (2001). Trade liberalization and per capita income convergence: a difference-in-differences analysis. Journal of International Economics, 55(1), 203-228. DOI: $10.1016 / \mathrm{S} 0022-1996(00) 00087-8$

Squalli, J. and Wilson, K. (2011). A New Measure of Trade Openness. The World Economy, 34(10), 1745-1770. DOI: 10.1111/j.1467-9701.2011.01404.x

Staiger, D. and Stock, J. H. (1997). Instrumental variables regressions with weak instruments. Econometrica, 65(3), 557-586. DOI: 10.2307/2171753

Treisman, D. (2000). The Causes of Corruption: A Cross-National Study. Journal of Public Economics, 76(3), 399-457. DOI: 10.1016/S0047-2727(99)00092-4

Vamvakidis, A. (2002). How robust is the growth openness connection? Historical evidence. Journal of Economic Growth, 7(1), 177-194. DOI: $\underline{10.1023 / \mathrm{A}: 1013418610712}$

Wacziarg, R. and Welch, K. H. (2003). Trade Liberalization and Growth: New Evidence, NBER Working Paper 10152, National Bureau of Economic Research, Cambridge, MA.

Wacziarg, R. and Welch, K. H. (2008). Trade liberalization and growth: new evidence. World Bank Economic Review, 22(2), 187-231. DOI: 10.1093/wber/lhn007

Windmeijer, F. (2005). A finite sample correction for the variance of linear efficient two-step GMM estimator. Journal of Econometrics, 126(1), 25-51. DOI: 10.1016/j.jeconom.2004.02.005

World Bank (2008). Unleashing Prosperity: Productivity Growth in Eastern Europe and the Former Soviet Union. World Bank Documents, Washington (2008), p. 42 available at:http://siteresources.worldbank.org/ECAEXT/Resources/publications/UnleashingPros perity.pdf

Yanikkaya, H. (2003). Trade openness and economic growth: a cross-country empirical investigation. Journal of Development Economics, 72(1), 57-89. DOI: 10.1016/S03043878(03)00068-3 